\title{
Antecedentes y ceremonial de los matrimonios militares en España
}

\section{Background and ceremonial of military marriages in Spain}

\author{
Javier Eiroa Escalada ${ }^{1}$ \\ Presidente de la Asociación de Comunicación, RRPP y Protocolo de Córdoba \\ jeiroa@telefonica.net \\ Juan José Bolívar Martín² \\ Jefe de Batería. Fuerzas Armadas. Ministerio de Defensa \\ juanjobolivar92@gmail.com
}

Recepción: 13/10/2021 Revisión: 25/10/2021 Aceptación: 05/11/2021 Publicación: 22/12/2021

\section{Resumen}

Nuestra sociedad suele tener la necesidad de exteriorizar y solemnizar los momentos culminantes de la vida, siendo el matrimonio uno de ellos. Hay numerosas publicaciones relacionadas con el matrimonio civil pero son muy escasas las relacionadas con el ámbito militar.

${ }^{1}$ Presidente de la Asociación de Comunicación, RRPP y Protocolo de Córdoba (ACRP), académico correspondiente de la Real Academia de Córdoba, jefe de protocolo del Instituto Español de Ciencias HistóricoJurídicos, miembro de la Sociedad de Estudios Institucionales, del Observatorio Profesional de Protocolo y Eventos (OPPE) y del equipo de protocolo en la Comandancia de la Guardia Civil de Córdoba.

2 Ingeniero en Organización Industrial por la Universidad de Zaragoza y Máster en dirección, organización y producción de eventos corporativos e institucionales por la Universidad Rey Juan Carlos. Experto en protocolo militar, miembro del Observatorio Profesional de Protocolo y Eventos (OPPE) y miembro de la Asociación de Comunicación, RRPP y Protocolo de Córdoba (ACRP). 
Las Fuerzas Armadas siempre se han considerado como un colectivo especial pero como integrantes de la sociedad no son ajenos a los cambios producidos a lo largo de la historia de España.

Este trabajo aborda las singularidades del matrimonio militar. En la primera parte, este artículo analiza la evolución histórica y normativa del matrimonio militar en España. En la segunda parte, para enmarcar el tema, se recoge la normativa vigente de aplicación en la materia considerándose los aspectos generales desde los puntos de vista civil y eclesiástico y, de manera específica, el ámbito militar.

Finaliza el trabajo detallando y analizando los distintos momentos en el protocolo y en el ceremonial concreto de una boda militar en la actualidad.

Palabras claves: Boda, Ejército, ceremonial, etiqueta.

\section{Abstract}

Our society usually has the need to externalize and solemnize the culminating moments of life, one of them marriage. There are numerous publications related to civil marriage, but those related to the military ones are very rare.

The Armed Forces have always been considered a special group but, as members of society, they are not alien to the changes that have occurred throughout the history of Spain.

This work addresses the singularities of military marriage. In the first part, this article analyzes the historical and normative evolution of the military marriage in Spain. In the second part, to frame the subject, the current applicable regulations on the matter are collected, considering the general aspects from the civil and ecclesiastical points of view and, specifically, the military sphere.

The paper will finish detailing and analysing the different moments in the protocol and in the specific ceremonial of a military wedding today.

Keywords: Wedding, Armed forces, ceremonial, etiquette.

\section{SUMARIO}

1. INTRODUCCIÓN

\subsection{Justificación}

1.2 Metodología del trabajo

\section{EVOLUCIÓN HISTÓRICA Y NORMATIVA}

3. REGULACIÓN DEL MATRIMONIO 
3.1 Matrimonio civil

3.2 El matrimonio en la liturgia católica

3.2.1 Constitución Apostólica Spirituali militum curae

3.2.2 Los Vicarios Castrenses y jefes de asistencia religiosa

3.2.3 Normas para confección de expedientes matrimoniales y celebración de matrimonios en la jurisdicción castrense

3.2.3.1. Expedientes matrimoniales

3.2.3.2. Situaciones especiales

3.3 Normativa de ámbito militar relacionada con el matrimonio

3.4 Participación militar en actos públicos de carácter religioso

3.5 Expresiones externas en actos públicos de carácter religioso

3.6 Otra normativa de carácter relacionada con los matrimonios militares

4. MARCO EMPÍRICO

5. CONCLUSIONES

6. BIBLIOGRAFÍA

\section{INTRODUCCIÓN}

La familia como institución que conecta a las personas con la sociedad ha sido analizada por (ALBERDI ALONSO, 1999: 14) quien concluye que en España está viviendo grandes cambios sujeta a un proceso de democratización general.

A este mismo convencimiento llevan también los grandes cambios que ha habido no sólo en lo referente a la profesión militar y a las características de la vida castrense, sino también en el común sentir de la sociedad de nuestro tiempo respecto a la naturaleza y función de las Fuerzas Armadas (FAS) en la convivencia de los hombres.

Las FAS siempre se han considerado como un colectivo especial, pero como integrantes de la sociedad no son ajenos a los cambios producidos. Ser miembro de las FAS entraña sus riesgos y al asumirlo desde el primer momento lleva a la mayoría de sus miembros a pensar en formalizar sus relaciones con una mayor intensidad que cualquier civil. 
Los humanos nos distinguimos del resto de animales por la posibilidad de pensar. Quizá por ello, y por una imperiosa necesidad de exteriorizar los momentos de júbilo, tenemos tendencia a solemnizar los momentos culminantes de nuestras vidas. (SURROCA SENS, 2008: 17).

Los bautismos, matrimonios y funerales son ritos solemnes relacionados con lo sagrado y tienen una gran tradición. Estas ceremonias existen en todas las culturas y acompañan a las personas en los acontecimientos que marcan profundamente la vida debido a algún cambio importante. Con el matrimonio las personas se hacen independientes de su núcleo familiar para crear una nueva vida o núcleo familiar.

Entre todas las celebraciones sociales, tal vez ninguna pueda compararse con la de la boda. En cualquier lugar y tiempo, siempre ha sido motivo de fiesta grande y una magnífica ocasión para reunir a familiares y amigos.

El matrimonio no tiene un origen eclesiástico, porque la figura del matrimonium ya se recogía en el derecho romano.

Para (FUENTE LAFUENTE, 2007: 336), la boda es un acto social porque ha "dejado de ser, en definitiva, un acto familiar para convertirse probablemente en el más importante evento de carácter social."

Este trabajo tiene una gran carga legislativa y de investigación donde se contrasta información transmitida con el paso del tiempo y las actualizaciones que se han ido implementando con el transcurso de los años debido a las nuevas tendencias. Conociendo nuestro pasado podremos llegar a comprender mejor la actualidad y saber el porqué de las cosas que nos rodean. Este artículo aspira a servir de guía para poder entender las pautas que se siguen en una boda castrense.

\subsection{Justificación}

Es relativamente habitual asistir a bodas en iglesias o ayuntamientos. Sin embargo, puede que no lo sea tanto el participar en una boda militar. Este tipo de ceremonias tienen algunos detalles muy característicos, que no siempre han estado permitidos, y que se abordan este artículo; por ejemplo, en éstas los invitados también pueden asistir con el uniforme al que tengan derecho según su normativa de aplicación.

Este tipo de enlaces tan característicos se organizan cuando uno de los contrayentes pertenece a las FAS o a la Guardia Civil, aunque actualmente también se están extendiendo a la Policía Nacional y a la Policía Local.

\subsection{Metodología del trabajo}


Este trabajo se fundamenta en que "la investigación social estudia la realidad social, los hechos, actores, relaciones y acciones sociales desde una particular perspectiva: mediante la aplicación del método científico." (BERGANZA Y SANZ, 2010: 24).

Para alcanzar los objetivos propuestos se utilizará un diseño metodológico sustentado en un procedimiento para analizar un ceremonial determinado combinando diferentes técnicas y utilizándolas de forma complementaria con el método del estudio de caso, en la modalidad de diseño de caso único y el análisis de contenidos en medios y redes.

Este artículo forma parte de un trabajo de investigación más amplio relacionado con el protocolo y ceremonial militar que ha requerido de varios recorridos metodológicos, cada uno de ellos con sus propias fuentes. Las fuentes de datos secundarios sobre las que recae el grueso de este trabajo han sido:

- Revisión de fuentes documentales. Se ha llevado a cabo un extenso repaso bibliográfico sobre normativa derogada, documentos de época y otro material disponible en fuentes abiertas, como el Boletín Oficial del Estado, el Ministerio de Defensa, Arzobispado castrense, etc. sobre el marco jurídico y materias como metodología y procedimientos del protocolo militar, civil y eclesiástico.

- Análisis de contenido mixto, tanto cuantitativo como cualitativo, recurriendo al análisis de contenidos de medios y de redes sociales.

- Observación directa. Por último, cabe destacar que los autores están profesionalmente involucrados en los ámbitos de actuación referidos en este trabajo, de forma que al estudio e interpretación de los datos extraídos del análisis de contenidos hay que sumar la observación participante como metodología transversal, que sirve también como herramienta válida para extraer las principales conclusiones.

En el marco teórico se ha realizado un análisis cualitativo del material estudiado que contempla el origen y la evolución de los compromisos matrimoniales en el entorno castrense español y se narra su evolución a lo largo de los años.

En el marco empírico los autores desarrollan una secuencia de la ceremonia nupcial.

\section{EVOLUCIÓN HISTÓRICA Y NORMATIVA}

Desde tiempos inmemoriales los enlaces matrimoniales entre personal civil y personal perteneciente a huestes armadas ha ido variando y no siempre de manera homogénea.

Durante la estancia de las legiones romanas en la Península Ibérica, la regulación aplicable determinaba que a los legionarios se les anulaba la posibilidad de contraer nupcias al ingresar en la Legión. Posteriormente, se modificó la norma en el sentido de que para poder casarse el legionario debía de cumplir un compromiso con el ejército de 20 años de servicio. 
Durante la Edad Media y hasta la llegada de los Reyes Católicos no se instauraría un ejército regular. El servicio militar se le presuponía a todos los súbditos del rey, ya fueran nobles, eclesiásticos o plebeyos. Estas mesnadas se componían para campañas concretas y una vez concluida la misma cada componente regresaba a su hogar, por lo que no había gran problema con que los combatientes tuviesen familia.

El ejército regular se instaura durante la dinastía de los Austrias. Durante esta época el principal eje de acción para las campañas bélicas eran los Tercios españoles donde estaba restringido casarse. Para evitar que los soldados crearan desmanes durante las campañas se permitía un porcentaje de mujeres públicas, en torno al 4 - $8 \%$ del contingente en cuestión, y eran comunes para todas las huestes (MONTSERRAT, 1946: 222). Sin embargo, este ratio de mujeres conllevaba problemas logísticos de avituallamiento y de moral. Con el tiempo, las mujeres que acompañaban a los Tercios solían tener hijos de los combatientes, que no podían mantenerlos ni prestarles la debida atención, por lo que los soldados terminaban estando más preocupados por sus familias que por la campaña. Así mismo, el sueldo del que disponían los componentes de los Tercios solía ser insuficiente, y más para mantener una familia, por lo que la pillería crecía en torno a los campamentos y los soldados se despreocupaban de servir para sobrevivir.

Como resultado de estas situaciones indecorosas para el ejército, Felipe IV mediante la Real Ordenanza de 28 de junio de 1632 (Art. 41) decide restringir los matrimonios de los miembros de sus ejércitos, siendo España la primera nación que reglamentó el matrimonio castrense. Inicialmente, esta restricción está orientada a prohibir los casamientos de capitán hacia arriba sin autorización expresa del rey y sólo permite que contraiga matrimonio una sexta parte de los soldados. En las Ordenanzas Segundas de Flandes, de 18 de diciembre de 1701, la pena por no cumplir estas restricciones podía llegar a la pérdida de sus puestos, llegando Felipe $\mathrm{V}$ a amenazar a los párrocos con la Real indignación, si autorizaban matrimonios vetados por las leyes militares.

Antiguamente, para acceder a los ejércitos o para ingresar en los altos puestos de la administración eran precisas las pruebas de nobleza y limpieza de sangre acreditadas a través del correspondiente expediente. En ese contexto parecía conveniente que cuando el militar fuera a desposarse lo hiciese con alguien que no desmereciera su ascendencia, por lo que se era preciso realizar averiguaciones sobre la limpieza de linaje de la futura esposa. En consecuencia, los militares españoles tuvieron limitada su libertad a la hora de contraer matrimonio, pues les resultaba necesaria la obtención de la correspondiente licencia de sus superiores para casarse.

En el siglo XVIII se van reglando aspectos jurídicos y sociales del ejército español con el objetivo de aumentar su profesionalidad. Dentro de los aspectos sociales que se regulan está el del matrimonio, aunque su reglamentación tiene sobre todo una significación política porque en este ámbito social los matrimonios de conveniencia eran aún más frecuentes que 
en el resto ya que con ellos se reforzaba el estatus y se perpetuaban los privilegios políticos y sociales (ÁLVAREZ Y CAÑAS, 2016: 109).

Con las condiciones que se promulgan para contraer matrimonio por parte de miembros del ejército se aprecia que la jurisdicción real está por encima de la eclesiástica.

Durante la época de los Borbones se sigue implementando normativa como la Ordenanza de Felipe V de 1728 y la "Ordenanza de S.M. sobre prohibición de Casamientos de Oficiales sin su Real permiso" que durante el reinado de Carlos $\mathrm{II}^{3}$ confirma la legislación anterior y añade nuevas trabas. Por ejemplo, la Real Licencia ya exigida a los oficiales para casarse solo sería concedida cuando la contrayente fuera "de tal calidad y circunstancias que mereciera enlazarse con oficial,... si la esposa pertenecía al orden civil era indispensable a ésta unir,..., una dote".

No obstante, se comprobó a lo largo de los años que cuantas más restricciones se instauraban, más infractores surgían y aumentaba el número de matrimonios clandestinos. Por este motivo estaban a la orden del día los indultos reales que solían concederse al finalizar alguna guerra, con ocasión de entronizaciones o bodas reales, como fue el concedido por Carlos IV el 5 de octubre de 1802 con motivo del matrimonio del príncipe Fernando con María Antonia de Nápoles.

A lo largo del convulso siglo XIX se producen innumerables vaivenes en la normativa sobre matrimonios militares de manera que, sin solución de continuidad, se suceden las siguientes normas:

- La Ley Orgánica del Ejército, de 9 de junio de 1821, dada por el Gobierno Constitucional, deroga toda la normativa citada anteriormente. En su Art. 131 ordena "que todos los militares pueden contraer matrimonio sin más requisitos ni licencias que los demás españoles, con solo llevar seis años de servicio". Requisitos que son aclarados mediante una Real Orden de 14 de enero de 1822 en el sentido de que los que lleven menos de seis años de servicio deberán pedir Real licencia y les será concedida si justifican con certificados del párroco y del alcalde la honestidad de la novia.

- Al restablecerse el absolutismo este régimen de libertad fue derogado por el Real Decreto de 1 de octubre de 1823.

\footnotetext{
${ }^{3}$ En esta Ordenanza se define que el Oficial que no obtenía la respectiva licencia quedaba despojado de su empleo, privado de fuero y su mujer sin derecho a la viudedad y merced de Tocas.
} 
- A propuesta de O'Donnell, la Real Orden de 30 de octubre de 1855 impone nuevas restricciones, al prohibir a los jefes y oficiales del Ejército solicitar Real licencia para casarse hasta tener la edad de 25 años.

- Narváez, en el preámbulo del Decreto de 13 de agosto de 1866, mantiene la prohibición a los jefes y oficiales de solicitar Real licencia para casarse hasta la edad de 25 años y a cambio deroga todas las disposiciones anteriores relativas a la obligación de justificar dote.

- Antes de cumplirse los tres años de vigencia de este Decreto, otro decreto del general Prim, de fecha 19 de abril de 1869 deroga la cierta flexibilidad existente que permitió un incremento en el número de bodas militares.

Una vez instaurada la 1a República se consideró la ineficacia de las prohibiciones y se permitió contraer matrimonio conforme la Ley de matrimonio civil, según la cual bastaba una certificación de libertad, expedida por el Jefe superior del Cuerpo y que entregaría el interesado al Juez Municipal para la formación del expediente matrimonial. Esta nueva situación no se prolongaría en el tiempo y se volverían a poner trabas a los militares para contraer matrimonio aunque esta vez durarían menos que en otras ocasiones. El Real Decreto de 27 de diciembre de 1901 reconoce en su preámbulo que es un problema arduo el determinar si los jefes y oficiales del Ejército deben tener o no una absoluta y completa libertad para contraer matrimonio y vuelve a exigir la licencia como requisito previo al matrimonio. Esta nueva normativa añade un motivo económico al habitual requisito de la permanente disponibilidad característica de la milicia, porque considera que el militar debía "presentarse ante la sociedad con el decoro que corresponde al puesto que en ella ocupa". Como curiosidad, el Art. 5 de este Real Decreto tipifica la conculcación de sus disposiciones como delito de desobediencia, lo que podía tener consecuencias muy graves para los que se casaran sin autorización.

El Decreto de 1901 es elevado a la categoría de Ley el 15 de mayo de 1902. Lo más destacado de este texto es que detalla las sanciones que han de aplicarse por infracción de las reglas establecidas en aquel. Entre ellas, la privación de derechos pasivos a las familias creadas por matrimonios celebrados sin licencia y separación del servicio del oficial contraventor. A la vez que amplía la pena de suspensión y multa de 250 a 2.500 pesetas que el art. 293 del Código de Justicia Militar señala para los párrocos que celebran matrimonios ilegales.

El Real Decreto de 24 de abril de 1924, durante la dictadura del general Primo de Rivera, regula nuevamente los trámites para la concesión de la Real Licencia que permitía a los militares contraer matrimonio. Esta norma mantuvo la necesidad de instruir un expediente iniciado a instancias del interesado, para acreditar que el matrimonio previsto no suponía riesgo de "menoscabar el prestigio del contrayente y su consideración" y reduce la pena separación del servicio para los que se casan sin Real licencia, a la de suspensión de empleo. 
Con la llegada de la 2a República, siendo Azaña el ministro de la Guerra, se vuelve a instaurar la libertad para casarse entre los militares. Las Cortes Constituyentes suprimieron la necesidad de que los militares obtuvieran permiso previo para contraer matrimonio y dispusieron que los generales, jefes y oficiales y sus asimilados así como las clases de tropa de segunda categoría que pertenecieran al Ejército, cualquiera que fuera sus situación, podrían casarse libremente, sin más limitación que la exigida por las leyes generales del Estado.

No obstante, durante la Guerra Civil, la Ley de 12 de marzo de 1938 restablece la vigencia del Código Civil, lo que supone la total derogación de la ley reguladora del matrimonio civil de 1932. Vuelve a reconocerse eficacia civil al matrimonio canónico, que se entendía era el compatible con los principios del nuevo Estado nacional y el matrimonio civil queda como marginal para aquellos que no profesaran la religión católica. Así mismo, es oportuno resaltar el carácter privilegiado que el Código Civil da al matrimonio de los militares porque, entre otros detalles, los dispensaba de la publicación de edictos fuera de la localidad de residencia si presentaban certificación de su libertad expedida por el Jefe del Cuerpo a que pertenecían.

Una vez que finaliza la Guerra Civil y el general Franco se instaura en el poder se vuelve a regular la licencia para contraer matrimonio. La Ley de 23 de junio de 1941 en su exposición de motivos recoge el propósito de "cuidar amplia y severamente las instituciones militares". Para ello, dispone que todos los generales, jefes, oficiales y asimilados así como el personal perteneciente al Cuerpo de Suboficiales de los ejércitos de Tierra, Mar y Aire, precisan de una licencia especial para contraer matrimonio que acreditara que la contrayente era española de origen, hispano americana ${ }^{4}$, filipina o nacionalizada en España, y que era concedida por el ministro del Ejército respectivo, cuando los peticionarios fueran generales, jefes u oficiales, y por los Capitanes Generales en los demás casos. Una Orden posterior extendió la vigencia de esta Ley al personal de la Guardia Civil y de la Policía Armada y de Tráfico.

Las regulaciones serían flexibilizadas mediante la Ley de 13 de noviembre de 1957 que se dicta para desarrollar el Concordato con la Santa Sede. En aquellos momentos era preciso modular la potestad exclusiva de la Iglesia en la regulación del matrimonio cristiano que llegó a negar la competencia del Estado en este punto y armonizó la legislación de los tres Ejércitos sobre la materia, reduciéndola a una ordenación común.

En sólo 13 artículos la ley detalla los matrimonios de las diversas escalas militares, las sanciones aplicables y el procedimiento para obtener la licencia matrimonial así como la manera de acreditar los requisitos y circunstancias recogidos en la misma.

${ }^{4}$ El Decreto-ley de 12 de abril de 1951 incluye en el término "hispanoamericano" a la mujer portuguesa o brasileña, como consecuencia de la ampliación que mediante Decreto-ley de 3 de enero de 1951 ya se había hecho antes para el matrimonio de los funcionarios de la carrera diplomática. 
Llegado el reinado de Juan Carlos I, mediante la Ley 85/1978, de Reales Ordenanzas de las FAS, se suprime la necesidad de solicitar licencia para contraer matrimonio. El Art. 177 afirma que "Todo militar tiene derecho a la libertad de pensamiento, de conciencia y de religión".

Sin embargo, la carrera de las armas sigue generando dificultades para formar una familia a sus miembros y sigue ocasionando a la institución los mismos inconvenientes logísticos y de personal que tenían los romanos hace más de dos milenios. No obstante, en la actualidad, se están impulsando medidas de conciliación familiar a la hora de seleccionar cambios de destinos en caso de tener una familia asentada en una determinada localidad diferente a la de destino, entre otras medidas.

\section{REGULACIÓN DEL MATRIMONIO}

\subsection{Matrimonio civil}

Actualmente, el matrimonio encuentra su principal regulación en el Código Civil.

El Art. 44 del Código Civil dispone que el matrimonio es una unión estable y permanente de dos personas del mismo o diferente sexo. Tramitado el expediente previo, conforme a la legislación del Registro Civil y acreditada la capacidad matrimonial, los contrayentes expresarán su consentimiento ante la autoridad competente y dos testigos, extendiéndose la inscripción o el acta correspondiente que se inscribirá necesariamente en el Registro Civil correspondiente.

No podrán contraer matrimonio, bajo pena de nulidad, los menores de edad no emancipados, las personas ligadas con vínculo matrimonial previo no disuelto, los colaterales por consanguinidad hasta el tercer grado, y los condenados como autores o cómplices de la muerte dolosa del cónyuge anterior, salvo dispensa otorgada por el Ministerio de Justicia.

\subsection{El matrimonio en la liturgia católica}

En la antigua Liturgia Hispana, desde el IV concilio de Toledo, aparecen cinco formularios distintos (FEROTIN, 1904: 433) ${ }^{5}$ relativos a la liturgia matrimonial, que van evolucionando hasta llegar al nuevo Ritual del Matrimonio promulgado el 19 de marzo de 1969 por Pablo VI. El cambio más sustancial respecto a rituales anteriores es que el sacerdote que interviene en la celebración litúrgica del matrimonio, aparece como testigo de una Iglesia

${ }^{5}$ Cita los Ordo nubentium, Ordo arrarum, Ordo ad benedicendum eos qui noviter nubunt, Prefatio solius persone, que primum nubit cum ea persona que iam nubsit, Item Ordo de secundis nutiis. 
que escucha y participa en una decisión de fe expresada por los esposos y como responsable y guía de una celebración de fe dentro de la asamblea litúrgica.

La Constitución Sacrosanctum Concilium sobre la Sagrada Liturgia del Concilio Vaticano Il al tratar del ritual del matrimonio afirma que se debe enriquecer el rito de la celebración e infundir los "deberes de los esposos". Además, se deben intentar conservar posibles tradiciones de la zona territorial en la que se celebre.

Siempre que se celebra el matrimonio dentro de la Misa, se usa el formulario de la misa ritual y vestiduras litúrgicas de color blanco; sin embargo, cuando se celebra en domingo o en una solemnidad, se dice la Misa del día, conservando la bendición de los esposos y, si parece oportuno, la fórmula propia de bendición final.

\subsubsection{Constitución apostólica Spirituali militum curae.}

La Iglesia ha querido cuidar siempre la asistencia espiritual de los militares, que constituyen un determinado grupo social y por las condiciones peculiares de su vida necesitan una concreta y específica forma de asistencia espiritual. Por esta necesidad, se fueron creando estructuras eclesiásticas para cada una de las naciones, presididas por un prelado dotado de las necesarias facultades.

El Concilio Vaticano II tuvo muy presente la acción de la Iglesia en el mundo moderno, también por lo que se refiere a la edificación y promoción de la paz en todo el orbe. Así, pues, los que forman parte de las FAS deben considerarse como instrumentos de la seguridad y libertad de los pueblos, pues desempeñando bien esta función contribuyen realmente a estabilizar la paz (Gaudium et spes, n. 79).

Se establecen algunas normas generales de aplicación a todos los "Ordinariatos" militares, hasta ese momento denominados "vicariatos castrenses" para que, dentro del ámbito de esta ley general, sean completadas y desarrolladas por estatutos establecidos por la Sede Apostólica para cada "Ordinariato".

En el Acuerdo entre el Estado español y la Santa Sede sobre la asistencia religiosa a las FAS y Servicio Militar de clérigos y religiosos, de fecha 05/12/1979, entre otras, se establecen las normas siguientes (Anexo I, Art.1-6):

- Los "Ordinariatos" militares, que también pueden llamarse castrenses, y que jurídicamente se asimilan a las diócesis, son circunscripciones eclesiásticas peculiares que se rigen por estatutos propios, respetando, donde existan, los Acuerdos vigentes entre la Santa Sede y los Estados.

- Para cada "Ordinariato" militar será nombrado como propio un Ordinario, dotado de dignidad episcopal, que goza de todos los derechos de los obispos diocesanos y tiene sus mismas obligaciones. 
- La jurisdicción del Ordinario militar es:

- Personal, la ejercida sobre las personas pertenecientes al "Ordinariato", aun cuando se encuentren fuera de las fronteras de la nación.

- Ordinaria, tanto en el fuero interno como en el fuero externo.

- Propia, aunque cumulativa con la jurisdicción del obispo diocesano, pues las personas pertenecientes al "Ordinariato" militar continúan siendo feligreses también de aquella Iglesia particular de cuyo pueblo forman una parte por razón del domicilio o del rito.

- Los cuarteles y los lugares reservados a los militares están sometidos primera y principalmente a la jurisdicción del Ordinario militar y subsidiariamente a la jurisdicción del obispo diocesano.

- Pertenecen al "Ordinariato" militar y están bajo su jurisdicción, entre otros (Art. 2):

- Todos los fieles que son militares y los empleados civiles que sirven a las FAS, con tal que se consideren así a tenor de las leyes civiles dadas para ellos.

- Todos los miembros de sus familias, es decir, esposos e hijos, incluidos aquellos que emancipados vivan en la misma casa; así como los parientes y los empleados domésticos que así mismo vivan en la misma casa.

- Los que frecuentan centros militares y los que se encuentran en hospitales militares, residencias de ancianos o lugares semejantes o prestan servicio en ellos.

\subsubsection{Los vicarios castrenses y jefes de Asistencia Religiosa}

Según los cánones 1110 y 1111 del Código de Derecho Canónico, el ordinario y el párroco personal, en razón de su oficio sólo asisten válidamente al matrimonio de aquellos de los que uno al menos es súbdito suyo, dentro de los límites de su jurisdicción. Ésta se extiende a cualquiera que sea la respectiva situación militar, a todos los militares de Tierra, Mar y Aire, a los alumnos de las academias militares, a sus esposas, hijos y familiares que viven en su compañía, y a todos los fieles de ambos sexos, ya sean seglares o religiosos, que presten servicios establemente bajo cualquier concepto o residan habitualmente en los cuarteles o lugares dependientes de la jurisdicción militar. Igualmente se extiende dicha jurisdicción a los huérfanos menores o pensionistas y a las viudas de militares mientras conserven este estado.

Cuando los capellanes castrenses por razón de sus funciones como tales tengan que oficiar fuera de los templos, establecimientos, campamentos y demás lugares destinados 
regularmente a las FAS, deberán dirigirse con anticipación a los ordinarios diocesanos o a los párrocos o rectores locales para obtener el oportuno permiso. (Art. 5.1).

3.2.3 Normas para la confección de expedientes matrimoniales y celebración de matrimonios en la jurisdicción castrense

Dada la trascendencia de las celebraciones de los matrimonios, desde octubre de 2000, se establecen las siguientes normas para todo el ámbito de la Diócesis Castrense:

\subsubsection{Expedientes matrimoniales}

- Sólo se podrá formar expediente matrimonial a los pertenecientes a la jurisdicción del vicariado castrense, determinados en la Constitución Apostólica Spirituali Militum Curae y especificados en los Estatutos del Arzobispado Castrense. Los contrayentes de otras jurisdicciones deberán necesariamente hacerlo en sus parroquias respectivas.

- El atestado de libertad expedido por los vicarios y delegados episcopales, correspondiente al medio expediente propio, será remitido al Vicario General de la Diócesis en que se vaya a celebrar el matrimonio previsto.

- La expedición de los atestados de libertad compete en exclusiva a los vicarios y delegados episcopales, sobre quienes recae a su vez la obligación de custodiar debidamente en sus archivos los expedientes recibidos de matrimonios bajo la cobertura jurisdiccional y con la correspondiente delegación de la parroquia territorial en la que dicho templo esté ubicado y en la que deberá inscribirse el matrimonio.

\subsubsection{Situaciones especiales}

Sin el conocimiento y autorización previa de la Vicaría General, no se podrá proceder a la elaboración de expedientes matrimoniales en las siguientes situaciones:

- Cuando uno de los contrayentes no sea católico.

- Matrimonios de menores de edad.

- Cuando al menos a uno de los contrayentes le haya sido declarado nulo un matrimonio anterior.

- En el caso de que al menos uno de los contrayentes esté divorciado de un matrimonio civil.

- Matrimonio de los que ya están casados civilmente entre sí. 


\subsection{Normativa de ámbito militar relacionada con el matrimonio ${ }^{6}$}

Con el objetivo de regular la asistencia religiosa al personal de las FAS, la Ley Orgánica 9/2011, de 27 de julio, de derechos y deberes de los miembros de las FAS señala que en ese ámbito se respetará y protegerá el derecho a la libertad religiosa y que se ejercerá de acuerdo con la Ley Orgánica 7/1980, de 5 de julio, de Libertad Religiosa. El Gobierno garantiza la asistencia religiosa que dimana de este derecho conforme con lo previsto en estas leyes y en la disposición adicional octava de la Ley 39/2007, de 19 de noviembre de la carrera militar.

La normativa general regula la garantía de la asistencia religiosa al personal creyente de cualquier confesión que forme parte del mismo y establece los criterios a seguir con motivo de la participación de miembros de las FAS en actos públicos de carácter religioso que se celebren en territorio nacional, dimanante de la ley orgánica citada en el párrafo anterior.

Las leyes 24/1992, 25/1992 y 26/1992, de 10 de noviembre, aprueban respectivamente el Acuerdo de Cooperación del Estado con la Federación de Entidades Religiosas Evangélicas, Federación de Comunidades Israelitas y con la Comisión Islámica en España.

En este sentido, y de acuerdo con el Art. 8 de cada una de las leyes mencionadas en el párrafo anterior, el personal de esas confesiones tiene derecho a participar en sus actividades religiosas y ritos propios, en los días y horas de precepto de las diferentes confesiones que la integran, previa la oportuna autorización de los jefes de UCO, siempre que no interfieran en las necesidades del servicio.

La asistencia religiosa será dispensada por ministros de culto designados por las diferentes confesiones religiosas, y autorizados por la Subdirección de Apoyo al Personal, previa solicitud del Jefe de UCO.

En todas las actuaciones que afecten a la asistencia religiosa, se observará el principio de igualdad, sin que exista discriminación por razón de religión. Así mismo se dará cumplimiento a las medidas sobre el tratamiento de los datos religiosos que contempla la normativa sobre protección de datos de carácter personal.

Los capellanes castrenses, además de aquellas actividades religioso-pastorales de atención a los miembros católicos de las FAS, intervendrán en aquellos actos en que tradicionalmente la celebración religiosa va unida a actos solemnes militares. La participación de los capellanes castrenses en el resto de las ceremonias solemnes militares se regirá por lo dispuesto en la OM 100/1994, salvo en lo relativo al acto de juramento o promesa ante la

\footnotetext{
${ }^{6}$ Extractado de la Norma General 01/16 “Asistencia religiosa en el Ejército de Tierra".
} 
bandera de España, que se estará a lo establecido en el artículo 7 y la disposición final décima de la Ley 39/2007.

\subsection{Participación militar en actos públicos de carácter religioso7.}

La participación de unidades militares en actos públicos de carácter religioso era habitual desde antes de la aprobación de la Constitución española de 1978. La participación de Unidades como un todo tenía, una vez designada la Unidad que participaba en los actos, carácter obligatorio para cada uno de sus miembros.

La participación del ejército en festividades de carácter religioso está regulada por la Instrucción General sobre Acciones de Cooperación en vigor, significándose que aquellos actos que con el uso y la costumbre hayan adquirido un carácter tradicional serán los únicos que se mantengan, no iniciando otros nuevos.

En lo que se refiere a la presencia de la Enseña Nacional, la Bandera se incorporaba a la formación porque era necesaria su presencia para rendir honores. Al pasar a ser esta participación una cortesía militar esta presencia ya no es obligatoria.

La participación de la Enseña Nacional en un acto de estas características debe tener en cuenta que la Bandera pertenece a una Unidad Militar concreta y su uso, fuera de lo determinado por el Reglamento de Honores, queda restringido a la autorización expresa del Jefe de la Unidad. La participación de la Bandera en un acto de carácter religioso donde no participa la Unidad como tal, sino voluntarios de la misma, justifica su ausencia.

\subsection{Expresiones externas en actos públicos de carácter religioso.}

Los honores militares los rinden solamente unidades militares y la Guardia Civil en sus actos específicos, así como en aquellos otros en los que se disponga su participación y esto excluye cualquier otra. En este sentido, a diferencia de los Honores Militares, la cortesía militar no debe interpretarse como una obligación sino como una deferencia hacia la esencia del acto en el que se participa. Se respeta así la esencia del acto religioso y se contribuye a perpetuar la tradición secular del acto, sin que ello suponga contravenir el Reglamento de Honores.

En lo que se refiere a la actitud que deben mantener los militares en los actos públicos de carácter religioso, ésta viene condicionada por la presencia de la Enseña Nacional y si el militar está en formación o fuera de ella.

Cuando se está en formación, la posición a adoptar es la de "firmes" y "arma descansada". El fusil estará armado de bayoneta o los sables desenvainados si está presente

\footnotetext{
${ }^{7}$ Basado en el Anexo IX de la Instrucción General 01/17 del Ejército de Tierra.
} 
la Enseña Nacional. En caso contrario, permanecerán sin armar y envainados los sables. No obstante, antes de la participación en cualquier acto se establecerá unas normas específicas para el acto en cuestión.

Se tendrá en cuenta lo establecido en la disposición adicional cuarta del Real Decreto 684/2010, Reglamento de Honores Militares, en lo referido a participación en actos religiosos. Cuando se autoricen comisiones, escoltas o piquetes para asistir a celebraciones de carácter religioso con tradicional participación castrense, se respetará el ejercicio del derecho a la libertad religiosa y, en consecuencia, la asistencia y participación en los actos tendrá carácter voluntario.

En cambio, en los actos oficiales que se celebren con ocasión de honras fúnebres, además de los honores que correspondan, se podrá incluir un acto de culto católico o de la confesión religiosa que proceda, teniendo en cuenta la voluntad que hubiera expresado el fallecido o, en su caso, la que manifiesten sus familiares. Por tratarse de actos en los que se interviene en representación de las FAS, la asistencia a los mismos tendrá consideración de acto de servicio.

La actitud de respeto a los actos en los que el Himno sea interpretado se expresará, en el caso del personal uniformado de las FAS y de las Fuerzas de Seguridad, efectuando el saludo reglamentario. En formación, la posición a adoptar será la de firmes y arma descansada/al brazo, con la excepción del jefe de la misma que efectuará el saludo reglamentario para mandos de Sección y Unidad superior.

\subsection{Otra normativa de carácter militar relacionada con los matrimonios militares.}

La normativa castrense vigente en la actualidad referida a bodas ya sean eclesiásticas o civiles -principalmente en ayuntamientos- es de uso interno. No obstante, una de las principales normas que afecta a este tipo de ceremonias es la Orden DEF/1756/2016, por la que se aprueban las normas de uniformidad de las FAS. En la norma octava, apartado c) indica que los contrayentes, padrinos y testigos utilizarán el uniforme de gala mientras que los asistentes utilizarán la categoría inferior. Sin embargo, el mismo punto da la posibilidad de seleccionar una uniformidad más solemne para los padrinos y contrayentes, como puede ser el uniforme de etiqueta o gran etiqueta. La clave que define este apartado es que los padrinos, contrayentes y testigos deben de llevar el mismo modelo de uniformidad y el resto de invitados una categoría inferior.

Debido al margen de libertad que deja la norma, el organizador, es decir, los contrayentes, seleccionarán el "dress code" a seguir. Esta es la clave de la cuestión y el motivo por el cual nunca habrá homogeneidad en las bodas militares, ya que unos militares prefieren una u otra modalidad de uniforme.

Una vez que los futuros esposos han seleccionado la modalidad de uniformidad que se va a vestir en el evento, los invitados deberán adaptarse y seguir las equivalencias de la Tabla 
1 (en las invitaciones suelen fijarse la uniformidad de los invitados para evitar posibles confusiones). Las versiones más comunes que suelen verse en este tipo de actos son las siguientes:

\begin{tabular}{|c|c|c|c|c|}
\hline $\begin{array}{l}\text { HORARIO } \\
\text { TIPO DE ACTO }\end{array}$ & PERSONAL CIVIL & FUERZAS ARMADAS & GUARDIA CIVIL & $\begin{array}{l}\text { CUERPO NACIONAL } \\
\text { DE POLICIAA }\end{array}$ \\
\hline $\begin{array}{l}\text { NOCHE Y ACTOS } \\
\text { GRAN SOLEMNIDAD }\end{array}$ & FRAC & GRAN ETIQUETA & GRAN ETIQUETA & GRAN GALA \\
\hline \multirow[t]{2}{*}{ NOCHE } & SMOKING & ETIQUETA & ETIQUETA & GRAN GALA \\
\hline & $\begin{array}{l}\text { CHAQUÉ } \\
\text { TRAJE OSCURO }\end{array}$ & GALA & GALA & $\begin{array}{l}\text { GALA DE } \\
\text { REPRESENTACION }\end{array}$ \\
\hline \multirow[t]{2}{*}{ MAÑANA Y TARDE -} & TRAJE OSCURO & $\begin{array}{l}\text { DIARIO } \\
\text { MODALIDAD A }\end{array}$ & $\begin{array}{l}\text { DIARIO } \\
\text { MODALIDAD A }\end{array}$ & $\begin{array}{l}\text { GALA DE } \\
\text { REPRESENTACIOON }\end{array}$ \\
\hline & TRAJE OSCURO & $\begin{array}{c}\text { DIARIO } \\
\text { MODALIDAD B }\end{array}$ & $\begin{array}{c}\text { DIARIO } \\
\text { MODALIDAD A }\end{array}$ & $\begin{array}{l}\text { GALA DE } \\
\text { REPRESENTACIOON }\end{array}$ \\
\hline $\begin{array}{l}\text { MAÑANA Y TARDE } \\
\text { (VERANO) }\end{array}$ & TRAJE OSCURO & $\begin{array}{c}\text { DIARIO } \\
\text { MODALIDADC }\end{array}$ & $\begin{array}{c}\text { DIARIO } \\
\text { MODALIDAD B }\end{array}$ & $\begin{array}{l}\text { GALA DE } \\
\text { REPRESENTACIÓN }\end{array}$ \\
\hline
\end{tabular}

Tabla 1. Equivalencias entre uniformidad militar y etiqueta civil.

Fuente: Elaboración propia

- Contrayentes, padrinos y testigos con el uniforme de gran etiqueta. El resto de asistentes militares vestirán con el uniforme de etiqueta y el personal civil con su correspondiente equivalente según Tabla 1. Esta modalidad es considerada la más solemne (Ver Figura 1). ${ }^{8}$

${ }^{8}$ Durante la boda del Príncipe Felipe se consideró que todos los asistentes deberían llevar el uniforme de gran etiqueta por la solemnidad del acto; por ello, todos los militares fueron con ceñidor dorado. En la Figura 1 se distingue al novio porque, a diferencia de sus compañeros, lleva un ceñidor dorado. 


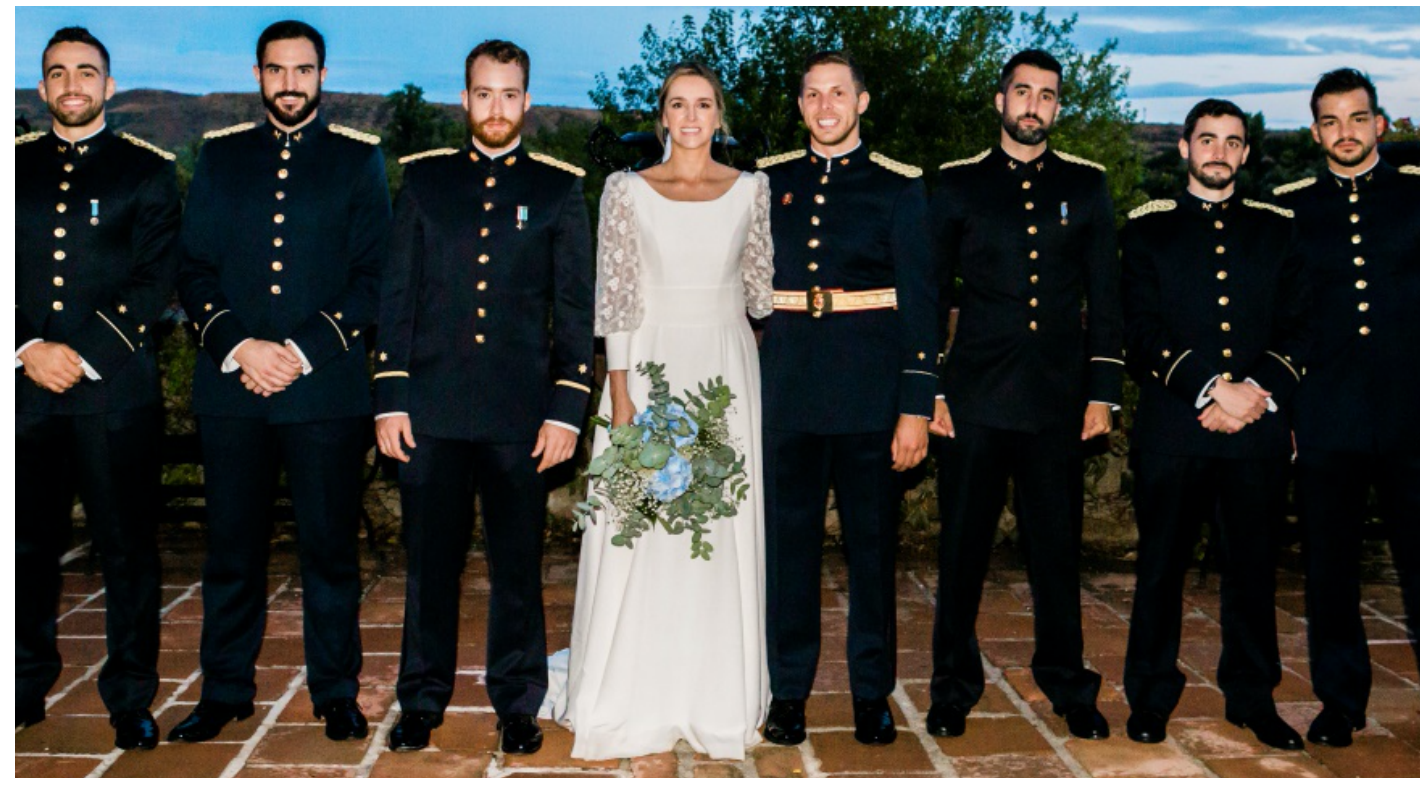

Figura 1. Novio con uniforme de gran etiqueta.

Fuente Ocho/Veinticuatro. Consultado el 20-05-21

- Contrayentes, padrinos y testigos con el uniforme de etiqueta. El resto de asistentes militares vestirán con el uniforme de gala y el personal civil con su correspondiente equivalente según Tabla 1. Si el personal asistente a la boda es mayoritariamente ajeno a las FAS los autores de este trabajo recomiendan emplear esta uniformidad. Aunque tiene menos solemnidad resalta a los contrayentes y a los padrinos sobre el resto de invitados militares (Ver Figura 2). Además, el personal civil podrá apreciar y distinguir la pluralidad de recompensas, cursos y demás detalles que se portan en este uniforme de las FAS y la GC.

Otro detalle relacionado con la uniformidad y que suele ser fuente de discrepancias es el sable. Dependiendo de si el CUMA es oficial o suboficial el sable tendrá una "dragona" dorada en el primer caso y plateada en el caso de suboficiales.

Relacionado con el sable, un punto incómodo para los asistentes castrenses es el "tiro" del sable. Tanto para oficiales como para suboficiales, el tiro es del mismo color, si bien el problema surge cuando algunos no lo tienen o no queda bien colocado con el uniforme a emplear. 


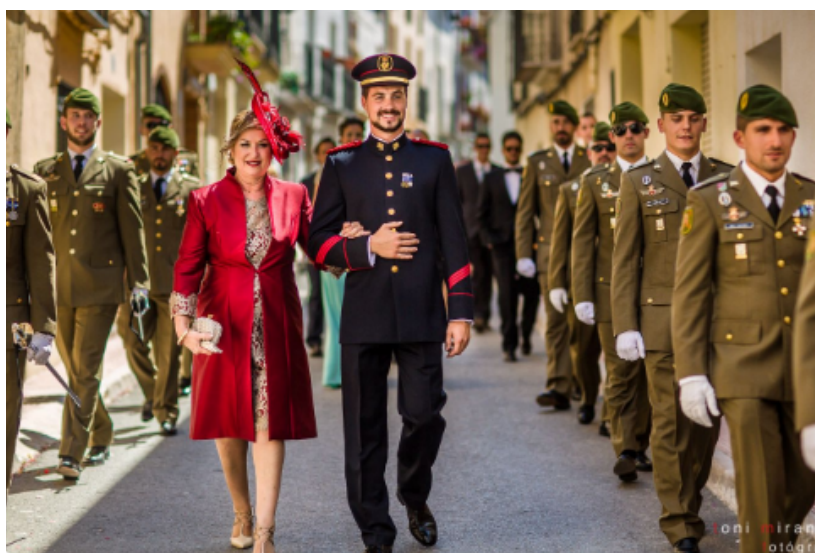

Figura 2. Novio con uniforme de gran etiqueta.

Fuente: Toni Miranda. http://www.tonifotografia.es/boda-militar-circulo-industrial/. Consultado el 23-05-21

\section{MARCO EMPÍRICO}

A continuación se analizan los puntos del ceremonial y del protocolo en las bodas militares celebradas en la Catedral de las FAS y en el resto de iglesias españolas. En algunas bodas estas pautas se implementan de manera completa, pero con frecuencia terminan dándose variantes que no se encuentran recogidas en normativa alguna:

- Los contrayentes deberán elegir una persona entre sus amigos o allegados para que, cuando llegue el novio, se lo comunique al responsable de la música (órgano, grupo musical,...) y puedan comenzar a interpretarse las melodías previstas. Al oír los primeros compases de la música los invitados sabrán que ha llegado el novio y se ponen en pie para esperar a la novia.

- En la actualidad, en el local donde va a celebrarse la ceremonia, y justo antes de que comience, se establece un pasillo con personal uniformado, en el recorrido entre la puerta del recinto y la última fila en que se encuentren sentados los invitados. Este pasillo permite que los contrayentes siempre estén acompañados o "escoltados" por sus seres queridos y de esa manera evitar que se sientan solos en ningún momento al llegar a la ceremonia (Ver Figura 3) 


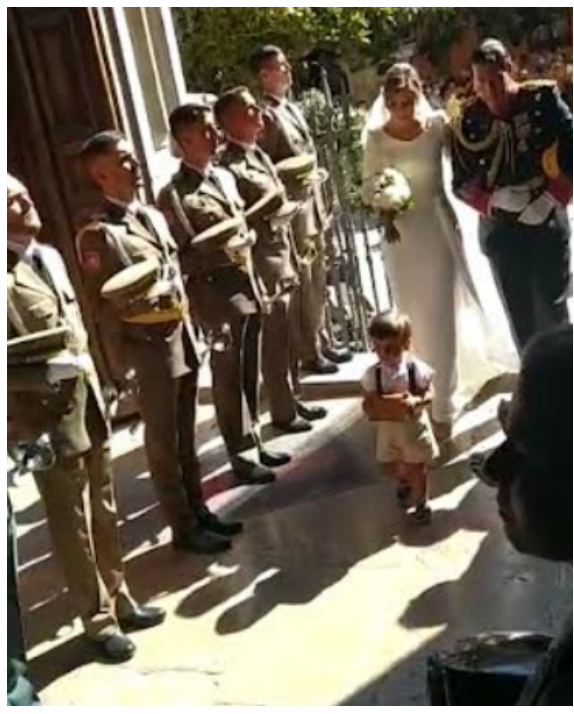

Figura 3. Piquete llegada de la novia.

Fuente Propia. Consultada el 06-08-21

- La distancia entre los componentes que forman el pasillo se adaptará a cada recinto, teniendo en cuenta que se establecerá dependiendo del número de efectivos y de la longitud del mismo.

- Los militares se encontrarán en la posición de "firmes" y con la prenda de cabeza en la mano derecha. Los autores recomiendan que, para este momento, se coloquen por alturas, de tal manera que los dos militares más altos estén lo más cercanos a la puerta de entrada y los de talla más reducida, al final del pasillo y más próximos a la presidencia del acto. De esta forma se logran los mejores tiros de cámara y se evita que los invitados sean deslumbrados con los destellos de los flashes.

- El novio irá desde la entrada de la Iglesia hasta el altar acompañado por la madrina, que estará situada a su derecha. En el altar esperarán a la novia mirando a la puerta de acceso. Una vez que el novio se encuentra en su posición de espera lo ideal es que la música baje su tono o se detenga. De esta forma los invitados podrán volver a sentarse o descansar hasta que llegue la novia.

- Una vez que llegue la novia, ésta permanecerá en la entrada hasta que comience de nuevo a sonar la música o la tonalidad de la misma cambie (con este cambio se vuelve a conseguir poner en alerta a los invitados). La novia en todo momento estará acompañada del padrino, que se situará a su izquierda y recorrerán el pasillo hasta llegar hasta el novio que la recibirá con un beso en la mejilla, en la mano o en la frente. 
- Mirando hacia el altar, la precedencia que se ha seguir en el altar es de izquierda a derecha: padrino, novia, novio y madrina.

- Inmediatamente finalizada la Consagración, en la Catedral Castrense se interpreta el Himno Nacional de España en su versión completa, de 52 segundos de duración. Los autores de este trabajo recomiendan encarecidamente interpretar el Himno Nacional en cualquier ceremonia de esponsales que se celebre en una iglesia tal y como viene regulado en el Reglamento de Honores Militares. Hay que recordar que el personal uniformado asistente a la ceremonia deberá de permanecer en la posición de "firmes" mientras suenan los acordes del Himno Nacional.

- Una vez que finaliza la ceremonia se procederá a montar el piquete de honores ${ }^{9}$ correspondiente. Este punto es uno de los más vistosos de una boda de las FAS y GC. El piquete deberá esperar a los novios en la entrada a la iglesia. El miembro más antiguo del piquete, con mayor graduación o antigüedad en el empleo será quien lo mande. Dependiendo de las ceremonias, existen casos en que los recién casados designan a otra persona que no sea la que reúna estos requisitos y es comúnmente aceptado.

- El piquete estará formado por dos hileras homogéneas de militares colocados frente a frente entre sí. Estos deben ser Cuadros de Mando (CUMA ${ }^{10}$ porque son los únicos que pueden portar sable según la normativa vigente. Si bien hoy en día se celebran numerosas bodas que organizan este piquete y cuyos componentes no son CUMA. Este piquete no sería correcto porque según las normas de uniformidad de las FAS solo los CUMA portan sable.

- La ordenación en estas hileras se aconseja que sea idéntica a la del primer piquete montado para formar el pasillo dentro del recinto, es decir, por alturas. Los dos componentes más altos se ubicarán lo más cerca posible de la puerta de la Iglesia para seguir en orden descendente de altura a medida que nos alejamos de la misma. Sin embargo, es costumbre que los dos últimos componentes del piquete sean elegidos expresamente por los contrayentes, aunque sean los más altos.

- El jefe del piquete tras comprobar que las distancias entre los componentes del piquete son iguales y que son pares ${ }^{11}$ mandará los movimientos correspondientes según la

\footnotetext{
${ }^{9}$ Según la RAE la palabra piquete viene definido como "Grupo poco numeroso de soldados que se emplea en diferentes servicios extraordinarios"

${ }^{10}$ Un Cuadro de Mando (CUMA) incluye a suboficiales y oficiales.

${ }^{11}$ En caso de que el número de los uniformados asistentes al acto no sea par, quedará un pico de una persona. Por nuestra parte recomendamos varias opciones: la primera es que el jefe de la formación quede fuera
} 
normativa de orden cerrado ${ }^{12}$ : en primer lugar, mandará "descanso", posteriormente, mandará "firmes", y finalmente dará la orden de desenvainar el sable.

- Una vez que los novios finalizan las fotografías en el altar con los familiares y amigos, la novia deberá colocarse a la derecha del novio, al contrario de lo que es habitual en las bodas civiles. Este detalle es debido a que, antiguamente, en los uniformes militares, el novio portaba el sable durante la celebración del matrimonio, tal y como vemos en la Figura 4.

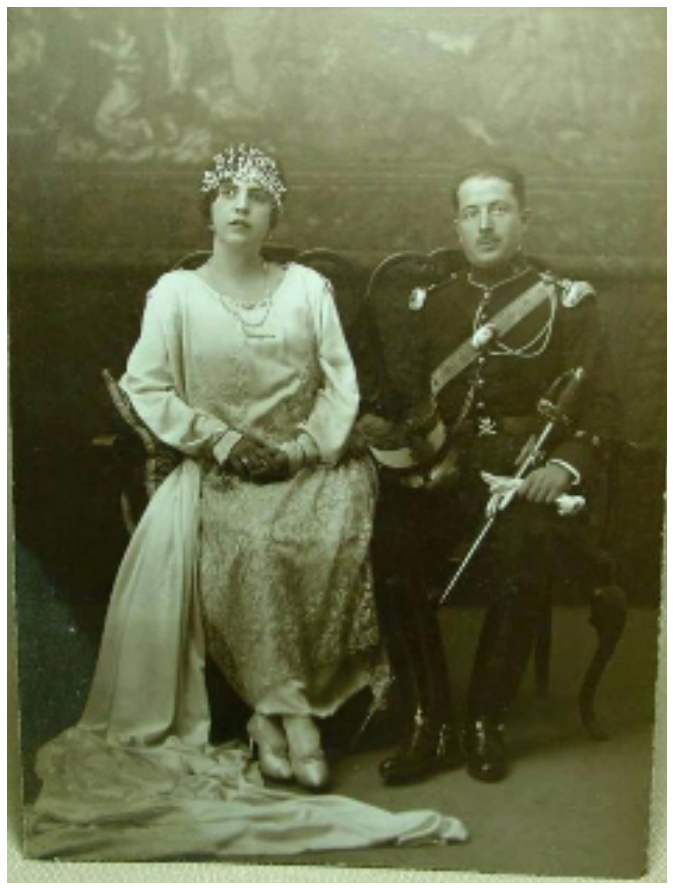

Figura 4. Pareja de recién casados según tradición militar.

Fuente https://www.todocoleccion.net/fotografia-antigua-fotomecanica/fotografiafoto-estudio-matrimonio-boda-militar-oficial-1930s $\sim$ 19345156. Consultado el 21-06-21

- Por el motivo mencionado en el punto anterior, y aunque hoy en día no se lleve sable en ninguna de las dos modalidades de las uniformidades contempladas para casarse, se sigue conservando esta tradición y se evitan situaciones como la de la Figura 5,

o bien forme al principio de la misma. Este Jefe de Formación no pondría su sable en 45 ㅇ, sino que se pondría en la posición de "presenten armas".

${ }^{12}$ La normativa de Orden Cerrado en las FAS determina los movimientos que se realizan en desfiles o paradas militares y como se deben realizar. 
donde se observa que entre los novios se encuentra el sable que importuna los movimientos de la novia.

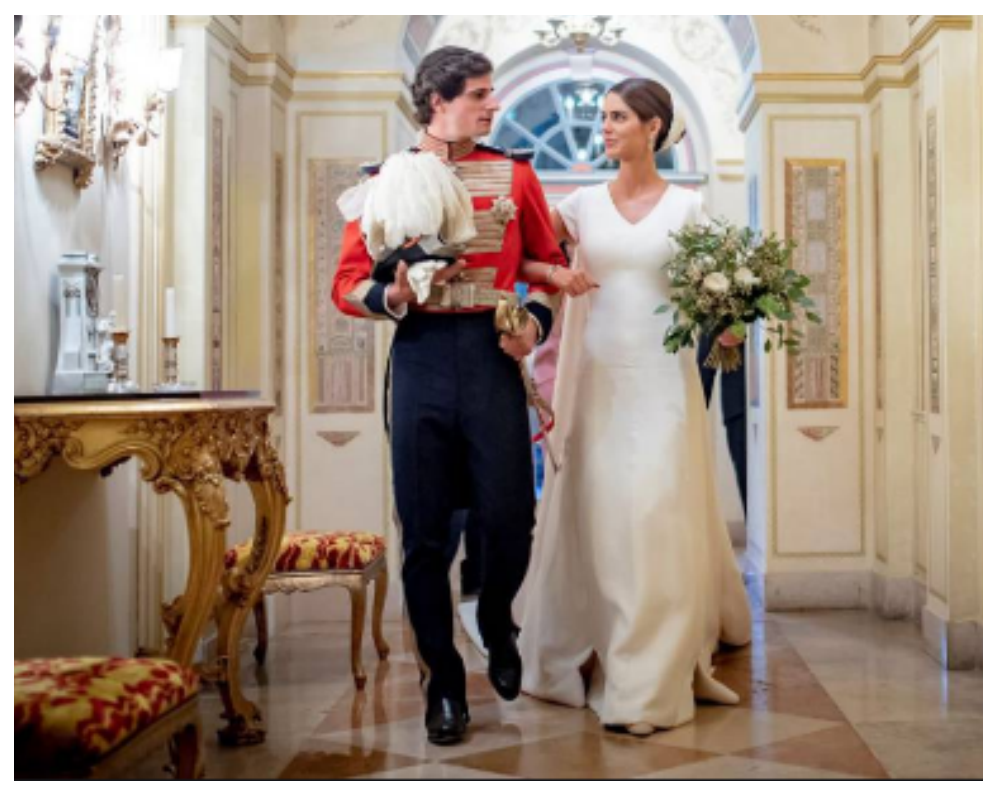

Figura 5. Pareja de recién casados (personal ajeno a las FAS).

Fuente https://www.hola.com/actualidad/galeria/20181008130939/sofia-palazueloduque-huescar-boda-hola/1/. Consultado el 21-06-21

- Cuando los novios se encuentran dispuestos a salir al exterior de la Iglesia, el jefe de piquete saldrá de su puesto en formación, se acercará a los contrayentes y les dará novedades de que el piquete está preparado para rendir los honores correspondientes. Estas novedades se deben dar al miembro de la pareja que sea militar, y si ambos lo son, deberá solicitárselo al que mayor graduación tenga de los dos. La voz tipo que deberá emplear el jefe del piquete debería ser: "A sus órdenes mi (graduación del empleo del uniformado que se case), solicito permiso para inicio y desarrollo de los actos". Si el novio es de menor gradación que del jefe del piquete deberá omitir la primera parte de la frase (a sus órdenes...).

- Una vez se autoriza, el jefe ocupa su puesto en el piquete y ordena "presenten armas". Aunque en la normativa de Orden Cerrado esta voz implique otro tipo de movimiento para esta ocasión se considera que el sable tiene que alcanzar un ángulo de 45으 para que forme un arco con el sable del militar que está en frente (Ver Figura 6).

- Una vez que el "arco de sables" esté formado, el orden de salida deberá ser: novios, padres del novio y padres de la novia. 
- Mientras los novios van avanzando a través del pasillo los miembros del pasillo comenzarán a repiquetear sables contra los sables. Para que el sonido quede de la forma más equilibrada, los integrantes de una columna dejarán el sable quieto y los de la otra golpearán sobre el sable que está quieto. Para evitar descoordinaciones, la columna de la derecha golpeará sobre la de la izquierda (según miramos si salimos por dónde salen los novios del recinto). Este sonido irá aumentando a medida que los novios avancen por el pasillo (hasta que los novios no sobrepasen la posición no podremos repiquetear nuestro sable con el sable del militar que tenemos enfrente).

- Al llegar al final del pasillo, los dos últimos componentes bajarán sus sables impidiendo el paso de los novios y el "best man" o mejor amigo del novio dirá la siguiente frase: "Si por pasillo quieres pasar, a la novia has de besar". Este momento suele ser la foto más buscada de todas las bodas castrenses (Figura 5). El best man deberá colocarse en el lado más próximo a la novia, es decir, en la columna de la derecha.

- En ocasiones los asistentes a la boda debido a la marcialidad de las voces del best man no saben cuándo han de lanzar el arroz o gritar el "vivan los novios". Los autores recomiendan esperar hasta que los novios lleguen al último arco de sables, para evitar que el ruido impida escuchar las voces pertinentes del best man.

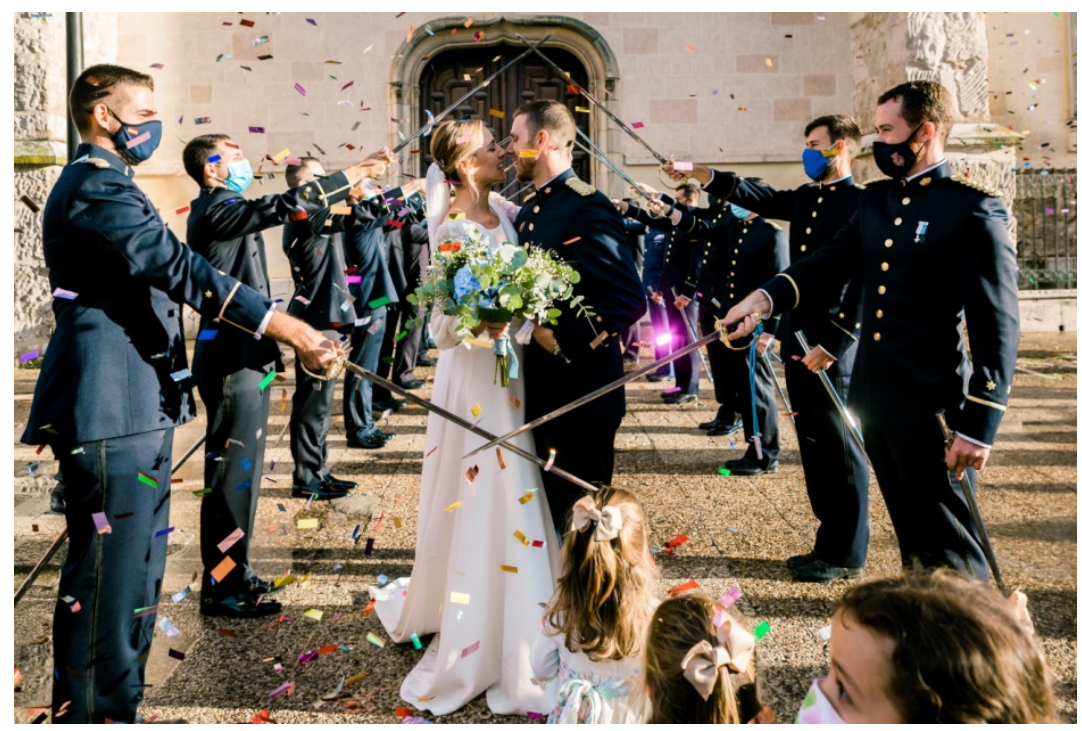

Figura 6. Piquete formando el pasillo.

Fuente Ocho/Veinticuatro. Consultado el 04/05/21

- Una vez que los contrayentes se besan, los dos últimos miembros del piquete les franquean el paso.

- Por último, el jefe del piquete mandará "descansen armas", "envainen sables" y romperá filas. En multitud de ocasiones el personal castrense cuando rompe filas suele 
gritar uno de los componentes de la formación una voz tipo a la que todos responden. Para esta ocasión sugerimos que el best man o el CUMA que mande la formación grite un "Vivan los novios" al que el resto de la formación gritaría un "iViva!"

Podrían narrarse más detalles sorprendentes o curiosos de este tipo de ceremonias, ya que cada boda suele ser una variante de la "tipificada". No obstante, se han desarrollado las características más representativas que pueden tener lugar en la boda de un miembro que pertenezca a la milicia.

\section{CONCLUSIONES}

Las FAS siempre se han considerado como un colectivo especial, pero como integrantes de la sociedad no son ajenos a los cambios producidos a lo largo de la historia. El ámbito castrense, sus costumbres y ceremonias, tampoco ha sido una excepción.

Los humanos sienten la necesidad de exteriorizar los momentos de júbilo y para ello se tiende a solemnizar momentos singulares de la vida como los bautismos, matrimonios y funerales, que son ritos solemnes relacionados con lo sagrado y tienen una gran tradición.

En el matrimonio las personas se hacen independientes de su núcleo familiar para crear una nueva vida o núcleo familiar, lo que siempre ha sido un problema para la profesión de las armas y la forma de afrontarlo ha ido evolucionando desde los inicios del ejército regular donde se prohibía taxativamente hasta la actualidad donde se fomenta el mismo.

Tras un viaje histórico que comienza con la estancia de las legiones romanas en la Península Ibérica, en las que para poder casarse el legionario debía de cumplir un compromiso con el ejército de 20 años de servicio, se salta hasta los Reyes Católicos. En ese periodo de tiempo todos los súbditos del rey participaban en mesnadas que se componían para campañas concretas, por lo que una vez concluida la misma las huestes regresaban a su hogar y no había gran problema con que los combatientes tuviesen familia.

El ejército regular se instaura durante la dinastía de los Austrias, momento en que el principal eje de acción para las campañas bélicas eran los Tercios españoles donde estaba restringido casarse. Para evitar que los soldados crearan desmanes durante las campañas se permitía un porcentaje de mujeres públicas, en torno al 4 - $8 \%$ del contingente, solución parcial que conllevaba problemas logísticos, de avituallamiento y de moral.

Como resultado de estas situaciones indecorosas para el ejército, Felipe IV en 1632 reglamenta el matrimonio castrense siendo España la primera nación en hacerlo. En las Ordenanzas Segundas de Flandes la pena por no cumplir las restricciones podía llegar a la pérdida de los puestos, llegando el rey Felipe $\mathrm{V}$ a amenazar a los párrocos con la Real indignación, si autorizaban matrimonios vetados por las leyes militares. 
Atendiendo a las condiciones que se promulgan para contraer matrimonio por parte de miembros del ejército se aprecia que la jurisdicción real está por encima de la eclesiástica.

Entre los siglos XVIII y XIX se reglan aspectos jurídicos y sociales del ejército español con el objetivo de aumentar su profesionalidad. Dentro de los aspectos sociales que se regulan está el del matrimonio, dotado de una gran significación política porque los matrimonios de conveniencia para reforzar el estatus y perpetuar los privilegios políticos y sociales eran aún más frecuentes que en el resto de la sociedad.

A lo largo de los años se comprobó que cuantas más restricciones se instauraban, más infractores surgían y aumentaba el número de matrimonios clandestinos, por lo que conforme se suceden los distintos regímenes se van alternando políticas más o menos rigurosas sobre la materia.

Con el advenimiento del régimen constitucional de 1978, en las Reales Ordenanzas de las FAS se suprime la necesidad de solicitar licencia para contraer matrimonio y este pasa a estar regulado como en el resto de la sociedad: bien por el Código Civil en caso de la ceremonia civil o por el ritual de la confesión religiosa que participen los contrayentes. En este trabajo sólo se ha analizado el ritual de la Iglesia Católica y sus peculiaridades dimanantes del Concordato con la Santa Sede, de la Constitución Apostólica Spirituali Militum Curae y de las características propias del Arzobispado Castrense.

Poniendo en relación ambos ámbitos, es conveniente destacar que la participación de unidades militares en actos públicos de carácter religioso era habitual hasta la aprobación de la Constitución española de 1978. En la actualidad esta participación está regulada por la Instrucción General sobre Acciones de Cooperación, en la que esta participación, antes obligatoria, pasa a ser una cortesía militar.

Así mismo, se analiza la normativa referida al uso de los símbolos nacionales - bandera e himno-, la uniformidad y los Honores Militares rendidos por unidades militares y de la Guardia Civil en sus actos específicos, en lo referido a participación en actos religiosos. En resumen, la cortesía militar no debe interpretarse como una obligación sino como una deferencia hacia la esencia del acto en el que se participa.

La ceremonia castrense de contraer nupcias nunca ha llegado a estar regulada de manera rigurosa por la normativa aunque la tradición se ha ido manifestando, unas veces clandestinamente y otras legalmente, en la ceremonia que tenemos en nuestros días.

Finalmente en este trabajo se desarrolla la secuencia y se analizan los puntos más singulares del ceremonial y del protocolo en las bodas militares celebradas en la Catedral de las FAS. En algunas bodas estas pautas se implementan de manera completa y rigurosa, como fue el caso del enlace matrimonial del entonces Príncipe de Asturias, pero con frecuencia terminan dándose variantes que no se encuentran recogidas en normativa alguna, pero el 
objetivo en cualquier caso es la celebración del matrimonio con la mayor solemnidad y vistosidad de los contrayentes así como por la importante repercusión social.

\section{BIBLIOGRAFÍA}

ALBERDI ALONSO, I. "La nueva familia española." Taurus, Madrid, 1999.

ÁLVAREZ Y CAÑAS, M.L. "El control institucional de los matrimonios bajo sospecha en el ejército. Entre la firmeza de un enlace de conveniencia y el engaño de la promesa fingida. Alicante 1751-1763." Revista de Historia Moderna, no 34. Alicante, 2016.

BERGANZA CONDE, M.R. RUIZ SAN ROMÁN, J.A.: "Investigar en comunicación", Mc Graw Hill, España, 2010.

FEROTIN, M. “Monumenta Ecclesiae Liturgica” (Vol. V). París, 1904.

FUENTE LAFUENTE, C. "Manual práctico para la organización de eventos. Técnicas de organización de actos II", 3ạ edición. Ed. Protocolo, Madrid, 2007.

MONTSERRAT, Sebastián. “La medicina militar a través de los siglos.” Madrid, 1946.

SURROCA SENS, J. "Manual de ceremonias civiles. Propuestas y textos para una liturgia laica". Brau Ed., Figueras (Gerona), 2008.

\subsection{Normativa consultada}

Acuerdo entre el Estado español y la Santa Sede sobre la asistencia religiosa a las Fuerzas Armadas y Servicio Militar de clérigos y religiosos, de fecha 05/12/1979. BOE no 300, de 15/12/1979.

Constitución Apostólica Spirituali militum curae del Sumo Pontífice Juan Pablo II sobre la asistencia espiritual a los militares. Roma, 21/04/1986. http://www.vatican.va/content/johnpaul-ii/es/apost_constitutions/documents/hf_p-ii_apc_19860421_spirituali-militum-

curae.pdf

Constitución Sacrosanctum Concilium sobre la Sagrada Liturgia. Roma. 1963. https://www.vatican.va/archive/hist_councils/ii_vatican_council/documents/vat-

ii_const_19631204_sacrosanctum-concilium_sp.html

Constitución pastoral Gaudium et spes, sobre la Iglesia en el mundo actual. Roma 07/12/1965. https://www.vatican.va/archive/hist_councils/ii_vatican_council/documents/vatii_const_19651207_gaudium-et-spes_sp.html 
Decreto aprobando el reglamento para la ejecución de las leyes de Matrimonio y Registro civil. «Gaceta de Madrid» núm. 348, de 14 de diciembre de 1870, páginas 1 a 4. https://www.boe.es/buscar/doc.php?id=BOE-A-1870-9848

Decreto autorizando al Ministro de este Departamento para presentar a las Cortes un proyecto de ley concediendo a todos los Generales, Jefes y Oficiales y sus asimilados y clases de segunda categoría, que pertenezcan al Ejército en cualquier situación, el derecho a contraer matrimonio sin más limitación que la exigida por las Leyes generales del Estado. Ministerio de Guerra. Gaceta de Madrid: núm. 244, de 01/09/1931, página 1578. (https://boe.es/datos/pdfs/BOE/1931/244/A01578-01578.pdf)

Decreto de 19 de abril de 1869, declarando que los Tenientes y Alféreces del ejército, al solicitar licencia para casarse, deberán acreditar haber impuesto con anticipación en la Caja general de Depósitos. Gaceta de Madrid: núm. 110, de 20/04/1869, página 1. (https://boe.es/datos/pdfs/BOE/1869/110/A00001-00001.pdf)

Instrucción General 01/17. "Ceremonias y actos militares del ejército de Tierra" Marzo de 2017.

Instrucción General 5/2008, de 28 de noviembre, de regulación de ceremonias y actos militares.

Ley 24/1992, de 10 de noviembre, por la que se aprueba el Acuerdo de Cooperación del Estado con la Federación de Entidades Religiosas Evangélicas de España. BOE núm. 272, de 12/11/1992. https://www.boe.es/eli/es/l/1992/11/10/24/con

Ley 25/1992, de 10 de noviembre, por la que se aprueba el Acuerdo de Cooperación del Estado con la Federación de Comunidades Israelitas de España. BOE núm. 272, de 12/11/1992. https://www.boe.es/eli/es/l/1992/11/10/25/con

Ley 26/1992, de 10 de noviembre, Ley 26/1992, de 10 de noviembre, por la que se aprueba el Acuerdo de Cooperación del Estado con la Comisión Islámica de España. BOE núm. 272, de 12 de noviembre de 1992, páginas 38214 a 38217. https://www.boe.es/eli/es/l/1992/11/10/26

Ley 39/2007, de 19 de noviembre, de la Carrera Militar. (La Disposición Derogatoria Única deja vigente el artículo 177 de la Ley 85/1978, de 28 de diciembre, de Reales Ordenanzas para las Fuerzas Armadas). BOE, núm. 278, de 20/11/2007. https://www.boe.es/eli/es/l/2007/11/19/39/con

Ley 85/1978, de 28 de diciembre, de Reales Ordenanzas de las Fuerzas Armadas. BOE no 11, de 12 de enero de 1979, páginas 753 a 764. https://www.boe.es/eli/es/l/1978/12/28/85

Ley de 12 de marzo de 1938, derogando la Ley de matrimonio civil de 28 de junio de 1932 y las disposiciones dictadas para su aplicación. Ministerio de Justicia. Boletín Oficial del Estado: 
$\begin{array}{lllll}\text { núm. } 516, \text { de 21/03/1938, páginas } 6353 & \text { a } & 6354 .\end{array}$ (https://boe.es/datos/pdfs/BOE/1938/516/A06353-06354.pdf)

Ley de 13 de noviembre de 1957 relativa a matrimonios militares, adaptada al Concordato con la Santa Sede. Jefatura del Estado. Boletín Oficial del Estado, no 286, de 14 de noviembre de 1957. https://boe.es/datos/pdfs/BOE/1957/286/A01088-01089.pdf)

Ley de 15 de mayo de 1902, referente á la penalidad en que incurren los Generales, Jefes y Oficiales que contrajeron matrimonio con infracción del Real decreto de 27 de Diciembre de 1901 y Real orden de 21 de Enero último. Ministerio de Guerra. Gaceta de Madrid: núm. 136, de 16/05/1902, página 756. (https://boe.es/datos/pdfs/BOE/1902/136/A00756-00756.pdf)

Ley de 23 de junio de 1941, por la que se dictan normas para contraer matrimonio los Generales, Jefes, Oficiales y Asimilados y el personal del Cuerpo de Suboficiales del Ejército. Jefatura del Estado. Boletín Oficial del Estado: núm. 192, de 11/07/1941, páginas 5190 a 5191. https://boe.es/datos/pdfs/BOE/1941/192/A05190-05191.pdf).

Ley disponiendo que todos los Generales, Jefes, Oficiales y sus asimilados y clases de tropa de segunda categoría que pertenezcan al Ejército, en cualquier situación, podrán contraer matrimonio libremente, sin más limitación que la exigida por las Leyes generales del Estado. Ministerio de Guerra Gaceta de Madrid: núm. 262, de 19/09/1931, página 1898 (https://boe.es/datos/pdfs/BOE/1931/262/A01898-01898.pdf)

Ley Orgánica 7/1980, de 5 de julio, de Libertad Religiosa. BOE núm. 177, de 24 de julio de 1980, páginas 16804 a 16805. https://www.boe.es/eli/es/lo/1980/07/05/7

Ley Orgánica 9/2011, de 27 de julio, de derechos y deberes de los miembros de las Fuerzas Armadas. BOE núm. 180, de 28 de julio de 2011, páginas 85320 a 85345 . https://www.boe.es/eli/es/lo/2011/07/27/9

Ley Orgánica del Ejército aprobada por las Cortes en 9 de junio de 1821. https://bibliotecavirtual.defensa.gob.es/BVMDefensa/es/consulta/registro.do?control=BMD B20150081384 consultado el10/06/2021

Ministerio de Gracia y Justicia (1889). Real Decreto de 24 de julio de 1889 por el que se publica el Código Civil, Boletín Oficial del Estado, núm. 206, de 25 de julio de 1889.

Norma General 01/16 "Asistencia religiosa en el Ejército de Tierra" Anexo IX. Participación militar en actos públicos de carácter religioso. 8 marzo 2016.

Normas para la confección de expedientes matrimoniales y celebración de matrimonios en la jurisdicción castrense. Octubre 2000. (Págs. 101-102) En Resumen documentos oficiales 19762009 del Arzobispado Castrense de España. https://arzobispadocastrense.com/publicaciones/otros-documentos 
Orden DEF/1756/2016, de 28 de octubre, por la que se aprueban las normas de uniformidad de las Fuerzas Armadas. BOE núm. 270, de 8 de noviembre de 2016, páginas 77494 a 77620. https://www.boe.es/eli/es/o/2016/10/28/def1756

Orden Ministerial 100/1994, de 14 de octubre, sobre regulación de Actos Religiosos en Ceremonias Solemnes Militares.

Ordenanza de casamientos, de 30 de octubre de 1760. https://bibliotecavirtual.defensa.gob.es/BVMDefensa/es/consulta/resultados_ocr.do?id=39 $053 \&$ forma=ficha\&tipoResultados=BIB $\&$ posicion $=10$

Ordenanzas Segundas de Flandes, de 18 de diciembre de 1701.

Real Decreto 684/2010, de 20 de mayo, por el que se aprueba el Reglamento de Honores Militares. BOE núm. 125, de 22/05/2010 https://boe.es/boe/dias/2010/05/22/pdfs/BOE-A2010-8188.pdf

Real Decreto 1560/1997, de 10 de octubre, por el que se regula el Himno Nacional. BOE no 244, de 11/10/1997. https://www.boe.es/eli/es/rd/1997/10/10/1560/con

Real Decreto 2945/1983, de 9 de noviembre, por el que se aprueban las Reales Ordenanzas del Ejército de Tierra. BOE núm. 285, de 29 de noviembre de 1983, páginas 32276 a 32292. https://www.boe.es/eli/es/rd/1983/11/09/2945 (Artículos 234 a 244 a.i.).

Real Decreto de 1 de octubre de 1823, mandando que para todos los empleos, comisiones, honores y toda clase de provisiones y nombramientos se me propongan personas que á cierta ciencia sean leales, amantes de Mi Persona y de los derechos de mi soberanía, prefiriendo en igualdad prudente de circunstancias á los que hayan padecido más por estas virtudes. Gaceta de Madrid: núm. 104, de 30/10/1823, página 385. https://boe.es/datos/pdfs/BOE/1823/104/C00385-00385.pdf)

Real Decreto de 13 de agosto de 1866, dictando varias disposiciones referentes a las condiciones que deben llenar los Jefes y Oficiales del ejército para contraer matrimonio. Ministerio de Guerra. Gaceta de Madrid: núm. 227, de 15/08/1866, página 1. (https://boe.es/datos/pdfs/BOE/1866/227/A00001-00001.pdf)

Real Decreto de 24 de abril de 1924, relativo a los requisitos exigibles para que los militares obtengan Real licencia para contraer matrimonio. Presidencia del Directorio Militar. Gaceta de Madrid: núm. 118, de 27/04/1924, páginas 530 a 531. (https://boe.es/datos/pdfs/BOE/1924/118/A00530-00531.pdf)

Real Decreto de 27 de diciembre de 1901, disponiendo que los Generales, Jefes y Oficiales del Ejército no pueden contraer matrimonio sin previa Real licencia. Ministerio de Guerra. Gaceta 
de Madrid: núm. 362, de 28/12/1901, página 1239. (https://boe.es/datos/pdfs/BOE/1901/362/A01239-01239.pdf)

Real Orden sobre los artículos 131 y 105 del decreto orgánico del ejército. Gaceta de Madrid: no 28, de 28/01/1822, pág. 168. https://boe.es/datos/pdfs/BOE/1822/028/A0016800168.pdf)

Real Orden de 30 de octubre de 1855, disponiendo lo conveniente sobre los requisitos que deben cubrirse en la celebración de los matrimonios de los Jefes y Oficiales del ejército. Ministerio de Guerra. Gaceta de Madrid: núm. 1038, de 07/11/1855, página 1. (https://boe.es/datos/pdfs/BOE/1855/1038/A00001-00001.pdf)

Real Ordenanza dada por Felipe IV el 28 de junio de 1632 